\title{
The Power of Belonging: Interactions and Values in Children's Group Play in Early Childhood Programs
}

\section{Gunnar Magnus Eidsvåg ${ }^{1}$ (D) $\cdot$ Yngve Rosell $^{1}$}

Accepted: 25 February 2021 / Published online: 26 March 2021

(c) The Author(s) 2021

\begin{abstract}
This article explores belonging as social interaction in relation to power and values. Power has both positive and negative aspects. We view children as active agents with the power to include or exclude others, create space for each other or set boundaries. The article shows how children's powers are limited by education staff's structural power and discusses the ethical and pedagogical implications of children's and staff's use of power. We find that well-considered use of power may widen children's horizons and provide them with social opportunities that they would otherwise miss. The data consist of video observation and interviews with children and teachers in three Early Childhood Education and Care settings in Norway. The article uses a lifeworld hermeneutical approach to study children's belonging as a complex and sometimes ambiguous phenomenon. The article shows that children's possibilities to position themselves and belong are made possible and limited by their social group via relational and structural power. By becoming aware of these contradictory tendencies, teachers can provide children with a variety of social experiences that promote belonging, which requires knowledge of how groups are formed by dynamic power relations that condition different social experiences.
\end{abstract}

Keywords Belonging $\cdot$ Play groups $\cdot$ Power $\cdot$ Values $\cdot$ Peer groups $\cdot$ Early childhood education

\section{Résumé}

Cet article examine l'appartenance en tant qu' interaction sociale selon une perspective de pouvoir et de valeurs. Le pouvoir possède des aspects à la fois positifs et négatifs. Les enfants sont perçus comme des agents actifs ayant le pouvoir d'inclure ou d'exclure, de créer un espace pour chacun ou de fixer des limites. L'article montre comment l'utilisation du pouvoir structurel du personnel limite le pouvoir des enfants, et il propose une discussion de considérations éthiques et pédagogiques

Gunnar Magnus Eidsvåg

gunnar.m.eidsvag@uis.no

1 Department of Early Childhood Education, University of Stavanger, Postboks 8600,

4036 Stavanger, Norway 
relatives à l'utilisation du pouvoir par les enfants et le personnel. Les auteurs trouvent qu'une utilisation réfléchie du pouvoir peut élargir l'horizon des enfants et leur fournir des opportunités sociales qui autrement leur auraient échappé. Les données consistent en observations de vidéos et en entretiens avec les enfants et les instituteurs de trois milieux d'éducation de la petite enfance en Norvège. Cet article fait appel à une approche herméneutique du monde de la vie pour étudier l'appartenance chez les enfants en tant que phénomène complexe et parfois ambigu. Cet article montre comment les possibilités pour les enfants de se positionner et d'appartenir sont rendues possibles mais sont aussi limitées par la communauté, à travers le pouvoir relationnel et structurel. En prenant conscience de ces tendances contradictoires, les enseignants peuvent fournir aux enfants diverses expériences sociales favorisant leur appartenance. Ceci nécessite la connaissance des groupes tels qu'ils sont formés par des relations dynamiques de pouvoir qui déterminent différentes expériences sociales.

\section{Resumen}

Este artículo explora el sentido de pertenencia como interacción social dentro del marco del poder y los valores. Se considera a los niños como agentes activos con el poder de incluir o excluir; crear espacios para cada uno; o establecer límites. El artículo muestra cómo el poder de los niños está limitado por el uso del poder estructural del personal educativo y plantea consideraciones éticas y pedagógicas del uso de poder de los niños y el personal educativo. Los autores descubren que un uso considerado del poder podría ampliar los horizontes de los niños y brindarles oportunidades sociales que de lo contrario no tendrían. La información se recolectó por medio de observaciones en video, así como entrevistas con niños y educadores, en tres contextos educativos de preescolar en Noruega. El artículo utiliza un método hermenéutico de vida cotidiana para estudiar el sentido de pertenencia de los niños como un fenómeno complejo y en ocasiones ambiguo. El artículo muestra la forma en que la comunidad hace posible y a su vez limita las posibilidades para que los niños se posicionen y pertenezcan, mediante poderes relacionales y estructurales. Al tener presente estas tendencias contradictorias, los educadores pueden ofrecer a los niños diversas experiencias sociales que promuevan su sentido de pertenencia. Esto requiere comprender que los grupos se forman por medio de relaciones dinámicas de poder que condicionan diversas experiencias sociales.

\section{Introduction}

Early childhood settings involve small communities that are structurally constituted by national laws and financial provisions. Within such communities, children and educational staff form relations for practical and personal purposes. In this study, we investigate children's belonging within early childhood education and care (ECEC) settings and how educational staff use their structural power in these communities to enhance children's belonging. Children's belonging has been studied from a variety of perspectives (Antonsich, 2010; Guo \& Dalli, 2016; Juutinen et al., 2018; Nutbrown \& Clough, 2009; Roffey, 2013). In our study, we adopt the perspective 
proposed by Yuval-Davis (2011), who theorised belonging through discursive categories that involve ethical and political values, ideologies and power relations. Through interactions, individuals make evident their thinking and intentions, which influences the boundaries constructed within groups. We regard children as active agents who participate in group formation in ECEC settings, and we acknowledge that children also have power, often more than they are aware of. This study investigates how education staff can use their power to help children flourish.

Our research is part of a larger research project that focuses on how belonging is formed in early childhood settings. The project is interdisciplinary and international and includes research teams from Finland, Sweden, Iceland, the Netherlands and Norway (University of Stavanger, 2020). In this study, we investigated how children expressed and negotiated belonging and how education staff facilitated these processes in three Norwegian kindergartens. In Norway, more than $90 \%$ of the children aged 1-6 years attend kindergarten. The increasing diversity of Norwegian society is reflected in kindergartens. In kindergarten, belonging is important not only for the individual child but also for the local community and, therefore, for the society at large.

Our research focused on children's belonging in their respective kindergarten rooms and play groups. We studied the processes of belonging in terms of power used by individuals. We understand power as both an enabling force and a restricting factor in children's interactions. In relationships and group dynamics, power is always an inherent feature. Being aware of how power works among children is important to understanding and ensuring belonging for every child in the group.

\section{Politics and the Power of Belonging: Theoretical and Research Perspectives}

We used the theoretical framework of Nira Yuval-Davis (2011) as described in Politics of Belonging: Intersectional Contestations. Yuval-Davis considered how a sense of belonging is constructed in terms of the following interrelated facets: social location, identity and attachment, and values. Social location refers to categories such as gender, age and ethnicity. For example, age may be a common social location for belonging in kindergarten, where age is used to form groups of children of similar age for care and early education. Belonging depends on our experiences within the groups to which we belong, and we use experiences within such groups to form identity and perceptions of ourselves. When we studied children's sense of belonging within peer groups, we focused on the relational power between individuals as a basic condition that describes the interactions, position and status of individuals within that group. We also considered how structural power used by education staff may interfere in children's relational processes.

Constructs such as participation, acceptance and rejection among peers are used across many strands of social research with children, with each construct having its own specific focus. Some of the most commonly used constructs in research on children include parent-child attachment (Schneider et al., 2001), aggression (Dodge, 2006; Ladd, 2006; Parker et al., 2006), prosocial behaviour and social skills (Burleson et al., 1992; Coplan et al., 2009; Hazen \& Black, 1989; Sommer, 2003; Walker, 
2009), position theory (Skånfors, 2010; Zachrisen, 2015), age and seniority (Palmadottír 2015) and friendships and protecting relationships (Greve, 2007; Johansson, 1999; Rosell, 2016; Rosell \& Johansson, 2019). These different theoretical constructs have enabled in-depth analyses to better understand how children interact and position themselves among peers. In our study, we build on this knowledge by focusing on power relations among children and how education staff deal with children's use of this power. Previous research has studied individual children or specific skills, and some studies have analysed children's interactions as dynamic processes and have identified both inclusion and exclusion mechanisms in peer groups (Rosell \& Johansson, 2019).

Yuval-Davis (2011) treated power as a central issue in her analysis of belonging. Power is one of several aspects of group dynamics (Tjora, 2018) and is often analysed in combination with critical theory (Grue, 2015). However, power is not only a phenomenon that exists among the traditionally powerful; instead, power is a relational phenomenon that is inherent in all relationships, including those among children.

\section{Power in Structural Contexts}

We understand power as a relational phenomenon, but it is important to also keep in mind that relational power is embedded in structural power (Engelstad, 2005). In Norway, kindergartens are organised on the basis of power structures designed by The Framework Plan for the Content and Tasks of Kindergartens (Kunnskapsdepartementet, 2017) and depend on the financial arrangements at the state and municipal levels. Among other functions, these structures legitimate kindergartens by detailing the pedagogical aims of kindergartens and designating the roles and responsibilities of the staff. As part of this structural framework, The Kindergarten Act also states the children's right to participate in decision processes, as specified by The United Nations Convention on the Rights of the Child (United Nations, 1989). Within these structures, power is related to the formal roles of the education staff, such as manager, pedagogical leader, early childhood teacher and others. From this perspective, children and their parents are users with certain rights related to their involvement in the kindergarten.

Relational power exists simultaneously with the formal power defined by the structures of an organisation. Relational and structural power often overlap but are sometimes in opposition with each other. The work context for education staff in Norwegian kindergartens is characterised by a relatively flat decision-making structure that is integrated as part of everyday practice, and there is little differentiation of work tasks between teachers and other staff members (Smeby, 2014).

Power as a relational phenomenon among children in Norwegian kindergartens has been analysed as a process characterised by both inclusion and exclusion mechanisms (Zachrisen, 2015). Children take on the roles of play facilitators and show initiative and resourcefulness to initiate and organise play activities in interactions with other children (Skånfors, 2010). Language capabilities and social skills are key resources for children when they negotiate positions in play (Skånfors, 2010). In this study, we understand relational power in children's peer and play groups to include 
both positive and negative processes: positive forces can maintain justice, access and status within the group, while negative processes are related to control, refusing to engage with other children's play initiatives, and manipulation (Hawley et al., 2007).

\section{The Current Study}

When studying relational and structural power, we focused on how the values of individuals manifested themselves and how social values were expressed in children's interactions and in staff's interventions in their everyday practices with children. In this study, we related Yuval-Davis's (2011) theoretical ideas on belonging to questions of power and values in children's peer groups in kindergartens.

We investigated how power relations affected children's experiences of belonging in play groups and how children expressed their sense of agency. We also explored how structural power and pedagogical insight may enable education staff to facilitate different dynamics in children's peer groups. Does the use of structural power enable education staff to create a variety of opportunities to enhance children's agency and provide the children with experiences of different social roles?

\section{Methodology}

This study's methodology is based on a hermeneutical approach with the assumption that children's experiences of power and belonging in social interactions can be understood and interpreted by analysing the encounters between children, education staff and researchers (Bengtsson, 2013; Gadamer, 2010; Van Manen, 1990). The data on social encounters were gathered through fieldwork in kindergartens, which involved using video observation of children's free play and organised activities planned by the staff as well as interviews with children and the staff. Using a hermeneutical approach, we sought to interpret the children's and education staff's experiences represented by the everyday practices in kindergartens. We also took into account the influence and power that researchers have when participating in a common world represented in kindergartens and collecting, analysing and presenting these experiences (Bengtsson, 2013).

\section{Research Context and Participants}

The research material was collected by the Norwegian researchers from the international research group participating in the research project, Politics of Belonging (2018-2020). Fieldwork was conducted in three kindergartens, with one kindergarten being private and two public. The Norwegian ECEC sector consists of approximately $50 \%$ public kindergartens and $50 \%$ privately owned kindergartens. However, regardless of ownership, all kindergartens receive the same amount of public funding and are regulated by the same legal framework, The Kindergarten Act (Kunnskapsdepartementet, 2005). The Kindergarten Act designates structural standards, such as staff qualifications, building characteristics and play area, and limits the amount 
of parent payments and owner dividends. This means that, from a structural point of view, the Norwegian ECEC sector has relatively consistent regulatory standards and provisions across the public and private sectors.

Around 100 children, aged between 3 and 6 years, and enrolled across the three kindergartens participated in the video observations. These observations were recorded in five-day periods on three separate occasions over three semesters. This resulted in approximately $80 \mathrm{~h}$ of video records across 45 days over a period of 18 months.

All the child interviews were conducted in kindergartens to reduce the influence that an unfamiliar person might have on the interview experiences (Jacobsen, 2018). Children from three kindergartens were interviewed. All the interviewed children had participated in the video observations and knew the researchers. The children were interviewed after the third observation period and were interviewed in pairs. By interviewing the children in pairs, we sought to encourage the children to reflect together on the recorded observations of their play and to find inspiration and support in each other. In the interview situations, the researchers were sensitive to the children's answers and their body language to make sure that the children were comfortable with the situation (Eide \& Winger, 2003).

We also interviewed staff members in groups. These interviews were conducted immediately after each period of video observations. In this manner, we could discuss what we noticed during the observations. We discussed how the children interacted and expected that the staff could provide background information to help us understand particular situations and relations between the children.

In all our fieldwork, we followed the ethical guidelines provided by the Norwegian Centre for Research Data. Participation in the project required written consent. For children, parents signed the consent forms, but the researchers, parents and staff also explained the research to the children to make sure that the children knew what participation implied and that it was voluntary.

\section{Data Collection and Data Analyses}

The video observations provided the starting point for the analysis of the children's interactions. When recording these video observations, we also tried to make sense of what we perceived was happening between the children in order to initiate the analytical process. After each observation period, we also interviewed the staff to discuss their views on the observed interactions between the children. In these unstructured interviews, we could test our interpretations, and the staff could contribute rich details, having known and followed the children over several years. In this process, the staff interviews served to validate or reject the researchers' interpretations.

We interviewed the children at the end of the third round of observations. By then, we knew the children and could organise paired interviews based on our knowledge of the children. The interviews were semi-structured so that the content of the interviews would have some consistency across the three kindergartens. 
Questions to the children were open-ended, and all responses by the children were received with acceptance and warmth.

The collected data were analysed from a hermeneutical perspective using content analysis (Jacobsen, 2018). Each set of data (videos and interviews from different kindergartens and time periods) was analysed on its own terms while keeping in mind the overall picture that the different datasets provided. In this way, we could understand differences across time periods and across the different kindergarten contexts in the overall dataset. Our analysis resembled a classical hermeneutical circle. We were inspired by van Manen's (1990) approach to data analysis means to produce common themes for further investigation. The themes that we discovered in our data highlighted important findings within the empirical material. The following two themes warranted a closer exploration of the data: (1) power to control the play situation and (2) power to set boundaries and choose playmates. We discuss these themes in the following section.

\section{Findings: Power and Belonging}

In our fieldwork, we met and spoke to many children and observed them in play. The children exercised power in several ways, usually in a relational context. Although power as a concept was not familiar to children, they were certainly aware of it as a social phenomenon for example, the children often negotiated issues related to decision-making and the fair distribution of roles or toys.

It was evident in the video materials that children exercised their power to enhance prosocial interactions, such as including others in a group or expressing solidarity with each other. There were several examples of these kinds of actions. However, such prosocial behaviours were not the focus of our study. We focused on the instances in which the children exercised their power in less prosocial ways and the staff's interventions in such situations. We found that the staff used their structural power to encourage and develop prosocial behaviour.

We analysed the data from the recorded interactions and the child and staff interviews to do with situations in which the children aimed to control the play and, therefore, their playmates. Moreover, we focused on the ways in which the children set boundaries and chose playmates and discussed these situations. Our findings showed that power relations were evident in the children's actions and in the agency that they exerted within their peer groups as well as in the staff's responses.

\section{Using Power to Control the Play Situation}

Our data showed that some children were eager to exercise their power and control play situations. Sometimes, they expressed this eagerness overtly, as in Carl's honest explanation:

Interviewer: But who decides what you play?

Carl: I decide what we play! 
Carl, who during the interview tended to answer vaguely and to shift the conversation towards his experiences and his belonging at home, responded quickly and clearly to the interview question about who decides what the children play. Carl explained that he had a best friend called Dimitri, and he seemed conscious about the power balance between him and Dimitri. The staff also confirmed the power relationships that were evident in children's play:

Staff member: We have our "Queens" and "Kings" in this peer group. These children want to decide the content of the play, and they can approach other children's play, take control of the play, and completely change the content.

The staff explained that Carl would try to control other children. We observed Carl playing with Dimitri. Below is a situation from our video observations:

Carl and Dimitri have used boxes and blankets to construct a water scene and a barrage, and they are engaged in building some boats in Lego. Carl is eager to show what he has built and repeatedly tells the staff and other kids in the room, "Look at my boat, look at my cool boat!" Dimitri is quieter and concentrates on building. Carl starts to shout, "ALARM, ALARM," and pushes his boat along the blankets. Dimitri follows him, and with a more slender/squeaky voice he says, "Alarm, alarm." Carl tells Dimitri where to carry their boats, saying, "Come here, Dimitri" and "This way," and Dimitri follows. The boys continue to carry their boats and occasionally shout, "Alarm." After a while, Carl tells Dimitri to stay behind some boxes and do the alarm signal while he carries his boat in the barrage. The staff in the room address Dimitri: "You can also be in the barrage," but Carl quickly interrupts, saying, "Please, he can play there later." Carl continues to carry his boat, and from behind the box you can hear a quiet and squeaky voice, "Alarm, alarm, alarm."

In this situation, there is continuity between Carl's own story of him being in charge in play situations involving Dimitri and what the staff and the researchers observed. Carl is conscious of his power and of being able to control Dimitri and the content and direction of the play. Carl takes a leading position (Zachrisen, 2015), and his interaction with Dimitri is like that of a guide who is eager to embark upon various initiatives but seldom open to the initiatives of others (Rosell \& Johansson, 2019; Sommer, 2003). The staff tried to intervene but left it up to the children to change the power relation that these interaction patterns had created. Carl continued to control and direct and Dimitri continued to follow these directions, seeming to be stuck in a position of being led (Zachrisen, 2015) and seldom able to pursue his own initiatives (Sommer, 2003).

In Carl's case, power was exercised overtly. However, the staff seemed to neglect or overlook it. In another kindergarten in this study, the opposite occurred. The use of power was covert, but the staff detected it and actively attempted to modify the power relations.

In an interview with two children from the study, Anja and Ashiko, friendship was discussed. The interviewer asked Anja what she usually played with her friends. Anja replied that they played mother, father and baby. 
Interviewer: When you play, who decides what role you should have?

Anja: They just choose what they want.

Interviewer: Everybody chooses?

Anja: Except being a baby.

Interviewer: Except being a baby?

Anja: Yes, because then there will not be anybody to look after [us].

It appeared that the most popular part to play was being a baby:

Interviewer: What is most fun, being a baby or looking after the baby?

Anja: It is most fun to be a baby.

Interviewer: Aha. What part do you usually play?

Anja: I am usually a big sister or a baby.

Anja explained that she had two younger sisters and an older brother in real life. In Anja's experience, the children in the group appeared to be on equal terms. She used the pronoun "they" when explaining how the children decide the distribution of roles. "They just choose what they want", she said. The only concern was that they cannot all play the most popular role at the same time because then the roleplay would not work. Anja preferred to be a baby, but when she had to choose a different role, she played the role of the big sister. This was the role she had in real life and therefore easily identified with it.

In our observations, Anja appeared to be resourceful and full of initiative. She had ideas of what to play and the skills to carry it through. The following description is an example of such an episode:

Four girls are playing a family. They are preparing a meal. Anja is playing a baby. She has a baby bottle in her mouth while she sits on the floor singing. Her body language is vigorous and confident. Two other girls stand around watching her, each with a trolley full of toy food. One of the girls leaves her trolley to fetch a chair. Anja smiles. "Oh, yeah," she says. "I could not sit on a chair since I am so little." "But we could," the other girl replies. Anja gets up and fetches a table. "This baby is strong even though she is little," she says, carrying the table. Anja keeps singing while she sets the table with food and cups from the trolleys. The other girls watch her and bring their trolleys closer. Anja empties one basket with food on the floor. "Oh, baby!" one of the other girls says with a comforting voice. Anja keeps singing and arranging the table.

When the table is set, the family starts to eat.

Anja sits on her knees while one of the "parents" sits with a doll on her lap. Two other girls are standing on the other side of the table pretending to eat. Anja makes baby sounds, indicating that she wants the parents' attention. The parents seem to be occupied eating and feeding a doll. After several attempts, Anja raises her spoon and says, "When I say dada, it means I want cake." "Ok," says the girl with the doll on her lap. Anja picks up the cake, and the meal continues. 
On this occasion, Anja ended up being the baby. The roleplay followed a narrative structure familiar to all the girls. They had played this game before. Even though we might say that all the girls narrate through their body language, this kind of narration involves, in a sense, acting out a role rather than controlling the direction and the content of the play. Decisions concerning the content of the narrative, such as who should act and what events should take place, may be attributed to the role of the narrator. This role may shift swiftly if all children show initiative, but it may also be taken up by one or a few of the children (Rosell \& Johansson, 2019).

In this episode, Anja clearly played the role of the narrator. The other girls reacted to her actions, and when they did show initiative (like fetching a chair), Anja framed the actions in relation to her own role. By taking on the narrator's role, Anja claimed a position of power. She was in charge, even though the role of the narrator seemed difficult to combine with the role of the baby. Anja combined the two effortlessly. She was the narrator who arranged the scene and explained what should happen, and she was the baby who could not speak and needed to be taken care of. Throughout the episode, Anja's body language was confident and vigorous, while the other girls passively watched her movements.

In this episode, the role of the narrator was a position of power. However, the position and the power connected to it appeared to be hidden from Anja. She did not appear to reflect upon the fact that all her ideas and suggestions both enabled the play while also limiting the other girls' possibilities to act out their own ideas. Anja expressed that she was not aware of the power relations that the different positions and interaction patterns create (Sommer, 2003; Zachrisen, 2015). We observed this pattern in various situations - for example, in board games, wardrobe transitions and free play.

During the interview with the staff, we spoke about dominance in play. They confirmed our impression of the power dynamics in the group of girls. The staff shared several examples of how these dynamics were acted out. Apparently, they tried to pay attention to the power relations between the children:

Interviewer: Some of the children have strong personalities.

Staff member: We try to take that into consideration so that the ones who often end up following someone else's lead are put together in a group. There, they

have more space to influence the play.

The staff used their knowledge of who influenced the play to regroup the children. In this manner, they attempted to create a social space for each child to express themselves in play. The arranging and rearranging of groups are acts of structural power. Used in the manner that the staff described, such acts of structural empower the less powerful children by creating a social space where said children can express themselves on their own terms. In this way, the children can experience a different sense of belonging.

This kind of practice is an expression of values. The values of each individual child to choose playmates are weighed up against the value of a group in which everyone is included as an autonomous and respected member. Yuval-Davis (2011) discussed values as the underpinnings of bordering and belonging. In what manner boundaries are set and "who belongs where" are questions related to 
values. In our study, when the education staff intervened and used their structural power to rearrange groups, it was an expression of their values. They regarded the belonging of every child and every child's possibility to influence the content of play situations to be more important than the right to choose playmates in every situation.

\section{Using Power to Set Boundaries and Choose Playmates}

Choosing whom to play with is an important part of every child's right to participate in the decisions that concern the child in the kindergarten (Johansson, 1999). This right is part of the Norwegian legislation for kindergartens. However, being able to choose friends is also a position of considerable power. Unfortunately, not all children are equally popular as playmates. The children may consciously or unconsciously develop a hierarchy of their most popular friends (Greve, 2007). The power to choose whom to play with is unequally distributed among the children. This kind of power can be overt or covert. In the instances where this power is hidden, the selection of playmates appears as an attraction towards the popular children rather than a rejection of the less popular. The situation with Ashiko discussed below provides an example covert power relation.

During several periods of observation, Ashiko and Steinar played with each other. This relationship developed because the play and the level of communication between the two children advanced during the research period. To the researchers, Ashiko and Steinar seemed to be intimate friends with well-developed capabilities to play together. In the interview with Ashiko and Anja, the researcher wanted to know more about this relationship between Steinar and Ashiko.

Interviewer: Do you have friends, Ashiko?

Ashiko: Yes.

Interviewer: Yes.

Ashiko: Thomas and Anders.

Anja: Thomas and Anders. Yes, mhm.

Ashiko: And Kristian.

Interviewer: And Kristian. Mhm, Steinar, is he a friend?

Ashiko: Yes.

Only when the researcher asked Ashiko whether he considered Steinar a friend did Ashiko confirm it. The play that these boys had enjoyed was not enough to make Ashiko mention Steinar as his friend, even though they had been playing just minutes before. Ashiko seemed to prefer other boys when they were present. Ashiko did not explain why he preferred the other boys, but it was not that he did not like Steinar; instead, the other boys simply appeared to be more attractive playmates.

In the interview with the staff, the researcher explored this issue further:

Staff member: We see that when the whole group are together, they [Ashiko and Steinar] do not play together.

Interviewer: That was interesting. 
Staff member: This is one reason why we split up the group of children. When we divide the group, we see that they find new playmates. We try to consider who really needs to be together.

The staff confirmed that the relationship between Ashiko and Steinar was not the same when the other boys were there. The two children never played together on such occasions. In these situations, Steinar struggled to find his place. The staff explained that when they grouped and regrouped the children, they were trying to open up social spaces for the children. In this case, they grouped Ashiko and Steinar together, though Ashiko's usual preferences were for other groups. In terms of power, the staff used their power to form structures that enabled new social constellations and different friendships to flourish.

\section{Discussion}

In this section, we discuss how power relations manifested themselves in the children's experiences of belonging in play groups and how the children exhibited a sense of agency in their interactions with their peers. We also examine the staff's use of structural power and their pedagogical insight to consider how the staff can create opportunities to enhance children's agency or enable children to experience different social roles. We found that the staff's use of power enabled the children in several ways, the most important being the following:

- Creating social space for the children who otherwise played secondary or passive roles in play.

- Providing socially strong children with experiences of engaging with other children's perspectives and initiatives.

Neither of these outcomes happens by itself. The staff reported that they had to support the children in the new groups and seriously consider the children's voices. The use of power was based on thorough ethical considerations of all the children's rights, wishes and needs. Below, we outline the implications for practice and identify directions for future research.

\section{Review of the Findings}

The different data excerpts provided examples of the various aspects of relational power in different groups of children. We found that power could be a positive force to facilitate various forms of play. Power was also grounded in children's abilities to show initiative, be creative and transform their knowledge and experience into the kind of play that is attractive to other children. The ability to inspire other children was also discussed in previous research as a positive aspect of play competence and continuity in children's peer groups (Burleson et al., 1992; Rosell, 2016; Walker, 2009). However, power may also have negative consequences in terms of exclusion and neglect or, in some cases, children's hegemonic control over certain types of 
play. Control and lack of openness to other children's initiatives can make play more susceptible to conflicts and termination of play (Rosell, 2016), and scholars have described this sort of negative play as less educational than the play in which control and initiatives are shared (Rosell \& Johansson, 2019).

In the examples we presented earlier, the children had different roles. Some children appeared to prefer adopting a leadership role (Zachrisen, 2015), being the guide and taking the initiative and controlling play (Rosell \& Johansson, 2019; Sommer, 2003). Other children often had marginal or secondary position. Our study found that the education staff attempted to provide these children with opportunities to take on a leading role in play.

Children's use of power may be expressed in overt or covert actions, and, sometimes, these power patterns can be hard to detect. It is particularly important to recognise such situations because when power structures are taken for granted, they may be experienced as natural or normal. Power structures designate the ways in which we belong, and belonging is an important part of our identities (Yuval-Davis, 2011). If children realise that they always end up playing secondary roles and following someone else's lead, they may interpret this position as an integral part of their identity.

The staff used their structural power to arrange or rearrange groups of children. Sometimes, they placed the children who preferred each other's company in the same group, and on other occasions, they made sure that the children who were often left out or given secondary positions were placed in a group in which they could take leading or equal positions in play. Therefore, the children had opportunities to form new relations involving new roles and to shift the balance of power within peer groups.

The examples discussed earlier showed that different values needed to be considered because values sometimes appeared to be in conflict. On the one hand, each child has the right to participate in the decisions that concern them. On the other hand, there is also value in every child having the opportunity to participate and belong in play on equal terms. When these values collide, resolutions imply the use of power (Yuval-Davis, 2011).

Children's use of power had several aspects. Some children used relational power to secure their influence and position, while others used power to create play situations. Children were aware of some aspects of their power, while other aspects seemed to escape them. The power to choose playmates entailed the power to disregard others, as exemplified by Ashiko and Steinar's case. Resourceful children, like Anja, created attractive play situations, while at the same time reduced other children's possibility to influence the direction and content of the play. Situations like these have positive and negative entailments for the children involved. We found that the education staff's reflective interventions could provide all the children with opportunities to take a leading or equal position in the play groups. The success of such interventions depended on the staff's knowledge of the children and their support and guidance in new play situations.

The staff used relational and structural power to ensure the participation and belonging of different children. There were several examples of such use of structural power. When staff members rearranged groups, new group dynamics came into effect. When 
different children were offered new roles, new negotiations about roles occurred. Within a new group, a child may play out a different version of themselves than they were previously able to. The child's ideas may gain greater support, or the child may realise that play based on another child's initiative can also be fun.

\section{Implications for Practice}

The data in this study emphasised the importance of staff support for children to gain different experiences of belonging within peer groups. It is important for education staff to know how belonging is related to power so that they can understand children's different social positions within peer groups and the nature of children's interactions with each other.

The process of arranging and rearranging groups involves difficult ethical considerations. It involves decisions that concern different values, such as each child's autonomy and every child's right to participate and belong (Yuval-Davis, 2011). The staff sometimes prevented the children from playing with their preferred playmates and directed them towards new relationships. This practice can come into conflict with children's right to participate in decisions that concern them and their peer group. This right has been included in The Kindergarten Act (Kunnskapsdepartementet, 2005) to do with ECEC. According to a narrow reading of this right in the Norwegian legislation, preventing children from playing with their preferred playmates could be considered a violation of this right. However, even though research indicates that kindergarten staff often interpret this right on an individual basis, one may argue that the right to participate requires more than a single individual's perspective. Rather, the right to participate should be interpreted as the right to be a full contributor in any group (Sagberg, 2012). Being a fully fledged member of a group means that individual rights must be considered in light of everyone's rights. One child's right to make individual decisions can be fulfilled only to the extent that it does not impinge on the possibilities of other children to exercise the same right. Therefore, a balance between individual and collective concerns is needed, and the staff of the ECEC centres are the ones who must maintain this balance.

It is important to point out that the practice of rearranging groups was always used in combination with other pedagogical approaches to play and social competence. Children's belonging involves various relationships and depends partly on children's capabilities in different play situations. In many situations, rearranging groups is not enough to ensure a child's sense of belonging. The use of structural power alone cannot solve all such social difficulties. Staff need to be present to support children and provide them with the time and the space to flourish (Zachrisen, 2015). Creating a warm and loving atmosphere must be a core component of the staff's responsibilities to enhance children's sense of belonging (Aslanian, 2015; Page, 2018). 


\section{Conclusions}

In our study, we found that education staff exercised moderation in their use of structural power. By studying children's belonging from different perspectives, our study underlined the fact that children are not always conscious of their roles and uses of power in play and of what it means to participate and belong. Clear counselling, and explanations to children, about the norms related to social interaction are a part of educators' responsibility when using structural power. Grouping and regrouping children to enable them to experience different social positions appeared to positively affect every child's right to participate and belong in a peer group. The strategy of regrouping needs to be one part of an integrated approach to pedagogical practice so that every child may experience the power of belonging.

The research presented in this article offers an in-depth analysis of social interactions and pedagogical strategies. Due to the nature of this kind of research, the conclusions cannot be generalised as facts that transcend their cultural embeddedness and the researchers' perspectives. However, we believe that there are recognisable patterns in social interactions that readers from various backgrounds may understand, identify with or be perplexed about.

Funding Open access funding provided by University Of Stavanger.. This research is part of the project "Politics of Belonging: Promoting children's inclusion in educational settings across borders" funded by NordForsk (Project Number 85644).

Open Access This article is licensed under a Creative Commons Attribution 4.0 International License, which permits use, sharing, adaptation, distribution and reproduction in any medium or format, as long as you give appropriate credit to the original author(s) and the source, provide a link to the Creative Commons licence, and indicate if changes were made. The images or other third party material in this article are included in the article's Creative Commons licence, unless indicated otherwise in a credit line to the material. If material is not included in the article's Creative Commons licence and your intended use is not permitted by statutory regulation or exceeds the permitted use, you will need to obtain permission directly from the copyright holder. To view a copy of this licence, visit http://creativecommons.org/ licenses/by/4.0/.

\section{References}

Antonsich, M. (2010). Searching for belonging: An analytical framework. Geography Compass, 4, $655-659$.

Aslanian, T. (2015). Getting behind the discourses of love, care and maternalism in early childhood education. Contemporary Issues in Early Childhood, 16, 153-165.

Bengtsson, J. (2013). With the lifeworld as ground: A research approach for empirical research in education-The Gothenburg tradition. Indo-Pacific Journal of Phenomenology, 13(sup1), 1-18. https:// doi.org/10.2989/IPJP.2013.13.2.4.1178

Burleson, B. R., Delia, J. G., \& Applegate, J. L. (1992). Effects of maternal communication and children's social-cognitive and communication skills on children's acceptance by the peer group. Family Relations, 41, 264-272.

Coplan, R. J., Debow, A., Schneider, B. H., \& Graham, A. A. (2009). The social behaviors of inhibited children in and out of preschool. British Journal of Developmental Psychology, 27(4), 891-905. https://doi.org/10.1348/026151008X396153 
Dodge, K. A. (2006). Translational science in action: Hostile attributional style and the development of aggressive behavior problems. Development and Psychopathology, 18(3), 791-814.

Eide, B. J., \& Winger, N. (2003). Fra barns synsvinkel: Intervju med barn-metodiske og etiske refleksjoner [From children's perspective: Methodical and ethical reflexions]. Cappelen akademisk forlag.

Engelstad, F. (2005). Hva er makt? [What is power?]. Universitetsforlaget.

Gadamer, H. G. (2010). Sannhet og metode [Truth and method]. Pax Forlag.

Greve, A. (2007). Vennskap mellom små barn i barnehagen [Friendship between small children in kindergarten] [Doctoral dissertation OsloMet]. Unipub forlag. https://skriftserien.oslomet.no/index.php/ skriftserien/article/view/551

Grue, J. (2015). Teori i praksis: Analysestrategier i akademisk arbeid [Theory in praxis: Analytical strategies in academic work]. Fagbokforlaget.

Guo, K., \& Dalli, C. (2016). Belonging as a force of agency: An exploration of immigrant children's everyday life in early childhood settings. Global Studies of Childhoods, 6, 254-267.

Hawley, P. H., Johnson, S. E., Mize, J. A., \& McNamara, K. A. (2007). Physical attractiveness in preschoolers: Relationships with power, status, aggression and social skills. Journal of School Psychology, 45(5), 499-521.

Hazen, N. L., \& Black, B. (1989). Preschool peer communications skills: The role of social statue and interaction context. Child Development, 60, 867-876.

Jacobsen, D. I. (2018). Hvordan gjennomføre undersøkelser? [How to carry out investigations?]. Cappelen Damm.

Johansson, E. (1999). Etik $i$ små barns värld. Om värden och normer bland de yngsta barnen i förskolan [Ethics in small children's world: On values and norm among the youngest children in ECEC]. Acta Universitatis Gothoburgensis.

Juutinen, J., Puroila, A. M., \& Johansson, E. (2018). 'There is no room for you!' The politics of belonging in children's play situations. In E. Johansson, A. Emilson, \& A. M. Puroila (Eds.), Values in early childhood settings. Springer.

Kunnskapsdepartementet. (2005). Barnehageloven [The Kindergarten Act]. Norway: Ministry of Education and Research.

Kunnskapsdepartementet. (2017). Forskrift om rammeplan for barnehagens innhold og oppgaver [The framework plan for the content and tasks of kindergartens]. Norway: Ministry of Education and Research.

Ladd, G. W. (2006). Peer rejection, aggressive or withdrawn behavior, and psychological maladjustment from ages 5 to 12: An examination of four predictive models. Child Development, 77(4), 822-846.

Nutbrown, C. M., \& Clough, P. (2009). Citizenship and inclusion in the early years: Understanding and responding to children's perspectives on 'belonging.' International Journal of Early Years Education, 17, 191-206.

Page, J. (2018). Characterising the principles of professional love in early childhood care and education. International Journal of Early Years Education, 26, 125-141.

Pálmadóttir, H. (2015). Communities in play: Young preschool children's perspectives on relationships, values and roles. University of Iceland.

Parker, J. G., Rubin, K. H., Erath, S. A., Wojslawowicz, J. C., \& Buskirk, A. A. (2006). Peer relationships, child development, and adjustment: A developmental psychopathology perspective. In D. J. Cohen (Ed.), Developmental psychopathology, theory and method. Wiley.

Roffey, S. (2013). Inclusive and exclusive belonging: The impact on individual and community wellbeing. Educational \& Child Psychology, 30, 38-49.

Rosell, Y. (2016). Mфter mellom barn-kontinuitet, dissonans og brudd i kommunikasjonen [Encounters between children: Continuity, dissonance and breaks in communication] [Doctoral dissertation, University of Stavanger].https://uis.brage.unit.no/uis-xmlui/handle/11250/2470746

Rosell, Y., \& Johansson, E. (2019). Små barns kommunikation: en dialektik mellam flöde och brott [Small children's communication: A dialectic between flow and breaks]. In: Berndtsson, I. C., Lilja, A., Ilona, R. (Eds.), Fenomenologiska sammenflätningar [Phenomenological perspectives] Daidalos AB.

Sagberg, S. (2012). Verdier, religion og danning [Values, religions and formation]. Fagbokforlaget.

Schneider, B. H., Atkinson, L., \& Tardif, C. (2001). Child-parent attachment and children's peer relations: A quantitative review. Developmental Psychology, 37(1), 86.

Skånfors, L. (2010). Tokens, peer context and mobility in preschool children’s position work. Nordic Early Childhood Education Research, 3, 41-53. 
Smeby, J. C. (2014). Førskolelæreryrket vil neppe utvikle seg til en profesjon [Pre-school teacher will hardly develop to a profession]. Forste steg, 10(2), 12-19.

Sommer, D. (2003). Barndomspsykologiske facetter [Facets of childhood psychology]. Systime Academic.

Tjora, A. (2018). Hva er fellesskap? [What is community?]. Universitetsforlaget.

United Nations. (1989). The United Nations Convention on the Rights of the Child. Office of the United Nations High Commissioner for Human Rights. http://www.unicef.org.uk/Documents/Publicationpdfs/UNCRC_PRESS200910web.pdf.

University of Stavanger. (2020). Tilhфrighet i barnehagen [Belonging in ECEC] https://www.uis.no/nb/ tilhorighet-i-barnehagen

van Manen, M. (1990). Researching lived experience Human science for an action sensitive pedagogy. State University of New York Press.

Walker, S. (2009). Sociometric stability and the behavioral correlates of peer acceptance in early childhood. Journal of Genetic Psychology, 170(4), 339-358.

Yuval-Davis, N. (2011). Politics of belonging: Intersectional contestations. Sage.

Zachrisen, B. (2015). Like muligheter i lek? Interetniske moter i barnehagen [Equal opportunities in play? Interethnic encounters in ECEC]. Universitetsforlaget.

Publisher's Note Springer Nature remains neutral with regard to jurisdictional claims in published maps and institutional affiliations. 